\title{
Rotational thromboelastometry (ROTEM) parameters in dogs with haemoperitoneum and their associations with clinical and laboratory signs.
}

\author{
Martin, A ; Kutter, Annette P N ; Sigrist, Nadja E
}

\begin{abstract}
Rotational thromboelastometry (ROTEM) is a viscoelastic coagulation test that allows the evaluation of haemostasis from clot formation to clot dissolution. The aim of this retrospective study was to describe the changes in haemostasis using ROTEM parameters in dogs presenting with spontaneous or traumatic haemoperitoneum and to evaluate any associations between clinical and laboratory parameters at presentation with the ROTEM. We hypothesized that the dogs would show signs of hypocoagulability and hyperfibrinolysis and that these changes would correlate with the degree of hypoperfusion. Clinical records were searched for a period of 5 years for dogs presenting with a haemoperitoneum und for whom a -ROTEM analysis at presentation was carried out. Forty dogs were identified, and various clinical and laboratory parameter (heart rate, blood pressure, blood glucose, lactate, serum albumin concentration, PCV (venous and abdominal), ionized calcium, $\mathrm{pH}$ and base excess) were retrieved. The following ROTEM parameters were analysed: extrinsic clotting time (ExTEM CT), clot formation time (ExTEM CFT), clot firmness (ExTEM MCF) and maximum lysis (ExTEM ML), as well as fibrinogen (FibTEM) CT and MCF. Compared to institutional reference intervals, dogs with haemoabdomen showed prolongation of ExTEM and FibTEM CT, ExTEM CFT and 50\% were hypocoagulable and 62\% thrombocytopenic. No hyperfibrinolysis could be detected. Multiple linear regression models showed an association between decreased base excess, trauma and ROTEM signs for hypocoagulability. Furthermore, age was associated with a stronger fibrin clot. In conclusion, $50 \%$ of the dogs presented hypocoagulable and changes in ROTEM parameters are similar to those seen with consumption coagulopathy. Base excess and trauma were associated with hypocoagulability, while increasing age was associated with a stronger fibrin clot.
\end{abstract}

DOI: https://doi.org/10.17236/sat00249

Other titles: Thromboelastometrie (ROTEM) Parameter und deren Assoziierung mit klinischen und Laborparametern in Hunden mit Hämoperitoneum

Posted at the Zurich Open Repository and Archive, University of Zurich

ZORA URL: https://doi.org/10.5167/uzh-186340

Journal Article

Published Version

Originally published at:

Martin, A; Kutter, Annette P N; Sigrist, Nadja E (2020). Rotational thromboelastometry (ROTEM) parameters in dogs with haemoperitoneum and their associations with clinical and laboratory signs. Schweizer Archiv für Tierheilkunde, 162(3):153-161.

DOI: https://doi.org/10.17236/sat00249 


\title{
Rotational thromboelastometry (ROTEM) parameters in dogs with haemoperito- neum and their associations with clinical and laboratory signs
}

\author{
A. Martin' ${ }^{1}$ A.P. N. Kutter ${ }^{2}$, N.E. Sigrist ${ }^{1}$ \\ ${ }^{1}$ Division of Critical Care Medicine, Department for Small Animals and 2Section of Anaesthesiology, \\ Department for Clinical Diagnostics and Services, Vetsuisse Faculty University of Zürich
}

\section{Thromboelastometrie (ROTEM) Parameter und deren Assoziierung mit klinischen und Laborparametern in Hunden mit Hämoperitoneum}

Als viskoelastisches Verfahren kann die Rotationsthromboelastometrie (ROTEM) die Hämostase von der Gerinnselbildung bis hin zur -auflösung aufzeichnen. Das Ziel dieser retrospektiven Studie war es die Veränderungen in der Hämostase an Hand von ROTEM Parametern bei Hunden zu beschreiben, die mit spontanem oder traumatischem Hämoabdomen vorgestellt wurden. Weiter wurde der Zusammenhang zwischen den ROTEM Parametern und ausgewählten klinischen und Labor-Parametern untersucht. Wir stellten die Hypothese auf, dass die Hunde Zeichen von Hypokoagulabilität und Hyperfibrinolyse aufweisen, und diese Veränderungen mit der Ausprägung der Hypoperfusion korrelieren. Innerhalb des 5-jährigen Untersuchungsrahmens wurden vierzig Hunde mit Hämoabdomen vorgestellt, für die bei Vorstellung eine ROTEM-Analyse durchgeführt wurde. Bei diesen Hunden wurden aus den Krankengeschichten klinische Parameter wie Herzfrequenz, Blutdruck, Glukose und Laktat, Serumalbumin, peripherer und abdominaler Hämatokrit, ionisiertes Kalzium, pH und Basenüberschuss herausgesucht. Die folgenden ROTEM Parameter wurden evaluiert: extrinsische Gerinnungszeit (ExTEM CT), Gerinnselbildungszeit (ExTEM CFT), Gerinnselstärke (ExTEM MCF) und maximale Lyse (ExTEM ML) sowie Fibrinogen (fib-tem) CT und MCF. Im Vergleich zu den Referenzintervallen zeigten die Hunde verlängerte ExTEM und FibTEM CT und verlängerte ExTEM CFT, 50\% waren hypokoaguabel und $62 \%$ thrombozytopenisch. Hyperfibrinolyse konnte nicht dargestellt werden. Multiple lineare Regressionsmodelle haben einen Zusammenhang zwischen einem verminderten Basenüberschuss, Trauma und ROTEM Zeichen für Hypokoagulabilität dargestellt. Weiter war Alter mit einem

\section{Summary}

Rotational thromboelastometry (ROTEM) is a viscoelastic coagulation test that allows the evaluation of haemostasis from clot formation to clot dissolution. The aim of this retrospective study was to describe the changes in haemostasis using ROTEM parameters in dogs presenting with spontaneous or traumatic haemoperitoneum and to evaluate any associations between clinical and laboratory parameters at presentation with the ROTEM. We hypothesized that the dogs would show signs of hypocoagulability and hyperfibrinolysis and that these changes would correlate with the degree of hypoperfusion. Clinical records were searched for a period of 5 years for dogs presenting with a haemoperitoneum und for whom a ROTEM analysis at presentation was carried out. Forty dogs were identified, and various clinical and laboratory parameter (heart rate, blood pressure, blood glucose, lactate, serum albumin concentration, PCV (venous and abdominal), ionized calcium, $\mathrm{pH}$ and base excess) were retrieved. The following ROTEM parameters were analysed: extrinsic clotting time (ExTEM CT), clot formation time (ExTEM CFT), clot firmness (ExTEM MCF) and maximum lysis (ExTEM ML), as well as fibrinogen (FibTEM) CT and MCF. Compared to institutional reference intervals, dogs with haemoabdomen showed prolongation of ExTEM and FibTEM CT, ExTEM CFT and 50\% were hypocoagulable and $62 \%$ thrombocytopenic. No hyperfibrinolysis could be detected. Multiple linear regression models showed an association between decreased base excess, trauma and ROTEM signs for hypocoagulability. Furthermore, age was associated with a stronger fibrin clot. In conclusion, $50 \%$ of the dogs presented hypocoagulable and changes in ROTEM parameters are similar to those seen with consumption coagulopathy. Base excess and trauma were associated with hypocoagulability, while increasing age was associated with a stronger fibrin clot.

Key words: Canine, haemoabdomen, haemostasis, hyperfibrinolysis, hypocoagulability https://doi.org/ $10.17236 /$ sat00249

Received: 04.09.2019 Acceptet: 06.01.2020
The authors declare no conflict of interest or financial disclosure. 
Rotational thromboelastometry (ROTEM) parameters in dogs with haemoperitoneum and their associations with clinical and laboratory signs

A. Martin, A.P. N. Kutter, N.E. Sigrist stärkeren Fibrin-Gerinnsel assoziiert. Zusammenfassend präsentierten sich 50\% der Hunde hypokoaguabel und die ROTEM Veränderungen entsprechen am ehesten einer Verbrauchskoagulopathie.

Schlüsselwörter: Canine, Hämoabdomen, Hämostase Hyperfibrinolyse, Hypokoagulabilität

\section{Introduction}

Haemoperitoneum is defined as an accumulation of blood in the abdominal cavity. In dogs, two main reasons can be distinguished: spontaneous haemoperitoneum, caused foremost by pathological changes in the spleen or liver and traumatic haemoperitoneum due to blunt or penetrating trauma. ${ }^{8,31}$

Severe bleeding and haemorrhagic shock with or without co-occurring trauma can lead to coagulopathies that are associated with increased mortality. ${ }^{6}$ Massive haemorrhage may lead to both loss and consumption of coagulation factors, fibrinogen and thrombocytes. ${ }^{28}$ Injury to the vascular system activates haemostasis through exposure of collagen to blood, leading to platelet adhesion and activation. Simultaneously, tissue factor is exposed and initiates the clotting cascade that subsequently leads to thrombin formation. ${ }^{46}$ Excessive thrombin formation may result in thrombosis followed by a consumption coagulopathy (disseminated intravascular coagulation (DIC)) which can occur with or without hyperfibrinolysis.19,21 Fibrinolysis-enhanced DIC is characterized by enhanced fibrinolysis in addition to activation of coagulation (thrombin formation) and consumption coagulopathy and leads to hypocoagulability and an increased risk of bleeding. ${ }^{21}$ This contrasts the antifibrinolytic phenotype of DIC, where haemostasis is in a hypercoagulable state. ${ }^{18}$

In people, abdominal haemorrhage is often associated with trauma, leading to acute traumatic coagulopathy. ${ }^{9}$ Hypoperfusion-associated generation of thrombomodulin-thrombin formation activates protein $\mathrm{C}$, which inhibits plasminogen activator inhibitor- 1 and results in hyperfibrinolysis and depletion of fibrinogen. ${ }^{11}$ Regardless whether consumption or trauma-induced coagulopathy predominates, massive bleeding leads to hypocoagulability and hyperfibrinolysis. ${ }^{28}$

The incidence and underlying pathomechanisms of coagulopathy in dogs with haemoperitoneum may be similar to those identified in people but are not well described. Fletcher at al. ${ }^{17}$ investigated thromboelastographic (TEG) profiles and coagulation factors of dogs with spontaneous haemoperitoneum and described evidence of hypocoagulability, protein $\mathrm{C}$ deficiency and hyperfibrinolysis.
Viscoelastic blood tests such as rotational thromboelastometry (ROTEM) allow the evaluation of haemostasis from clot formation to clot dissolution in a whole blood sample. With ROTEM, the viscoelastic properties of whole blood are measured under low shear conditions, are graphically depicted in a profile and several parameters are measured and calculated by the ROTEM device. Specific coagulation activators are available that allow evaluation of both ex- and intrinsically activated haemostasis (ExTEM and InTEM assay, respectively) and evaluation of the fibrin component of the clot (FibTEM test which has cytochalasin D, a platelet inhibitor, added). Furthermore, ROTEM analysis is used to describe hyperfibrinolysis in people ${ }^{38,43}$ and has been used to describe it in dogs and cats. ${ }^{39,40}$

To the authors knowledge there is only one publication investigating haemostatic changes in dogs presenting with haemoperitoneum. ${ }^{17}$ This study investigated only dogs with spontaneous haemoperitoneum and used TEG among other parameters. As ROTEM analysis may be superior in identifying hyperfibrinolysis ${ }^{1}$ and allows assessment of fibrinogen function, the goal of this study was to describe haemostatic changes in dogs presenting with haemoperitoneum by means of ROTEM analysis and to evaluate associations between clinical and laboratory parameters at presentation with ROTEM parameters. We hypothesized that the dogs would show signs of hypocoagulability and hyperfibrinolysis and that these changes would correlate with the degree of hypoperfusion.

\section{Material and methods}

Clinical records were searched for dogs that have been presented at the Small Animal Clinic of the Vetsuisse Faculty, University of Zurich, Switzerland, with a haemoperitoneum und for whom a ROTEM analysis at presentation was carried out. The search covered the period of five years (September 2013 - January 2019).

A haemoperitoneum was defined based on an abdominal effusion with either a packed cell volume (PCV) $>20 \%{ }^{31}$ or an abdominal PCV exceeding the venous PCV in anaemic patients, or identification of a haemorrhagic source during surgery. Dogs that were treated 
with fluids other than an isotonic crystalloid or with drugs interfering with coagulation (tranexamic acid, vitamin $\mathrm{K}$, non-steroidal anti-inflammatory drugs, antiplatelet drugs or toxins such as rodenticides) prior to ROTEM analysis were excluded from the study.

For each dog breed, age, sex, weight and cause of the haemoperitoneum and amount of crystalloid fluid prior to ROTEM analysis were retrieved from patient records. The following clinical and laboratory parameters at admission were recorded: heart rate (HR), rectal temperature, systolic arterial blood pressure (SAP), mean arterial blood pressure (MAP), glucose, lactate and serum albumin concentration, PCV (venous and abdominal), ionized calcium (iCa), $\mathrm{pH}$ and base excess. The shock index was calculated from HR/SAP. ${ }^{27}$ Biochemical parameters were compared to institutional reference intervals (RI).

All ROTEM tracings were checked visually and excluded if an artefact was suspected. The ROTEM analysis was performed using citrated whole blood stored for 10-20 minutes at $37^{\circ} \mathrm{C}$ and followed the clinic-specific protocol, which is based on manufacturer guidelines (Tem Innovations $\mathrm{GmbH}$ München) and published guidelines. ${ }^{16}$ The following parameters were extracted from the ROTEM database and copied into a spreadsheet for further analysis: clotting time (CT), which is defined as the time from activation until the fibrin formation starts. The clot formation time (CFT) characterizes the kinetics of clot formation and is defined as the time from start of fibrin formation until a clot of $20 \mathrm{~mm}$ is reached. The maximum clot firmness (MCF) shows the absolute strength of the clot and is given in $\mathrm{mm}$. Furthermore, maximum lysis (ML) was analysed to describe how many percent of the clot is lysed at 60 minutes. A non-measurable FIBTEM-MCF ("green line") was defined as $0 \mathrm{~mm}$. If MCF in any of the profiles did not reach $20 \mathrm{~mm}$, CFT was defined as 3600 seconds, as all profiles were run for 60 minutes.

Results were compared to institutional reference intervals (RI) generated from 49 dogs (Jud et al., manuscript in preparation). Hypo- or hypercoagulability was defined as at least two of the following ROTEM parameters being hypocoagulable or hypercoagulable, respectively: ExTEM-CT, -CFT, -MCF and FibTEM-MCF. Hypofibrinogenemia was defined as FibTEM-MCF $<2 \mathrm{~mm}$.

Treatment following ROTEM analysis was retrospectively extracted from patient records. The need for surgery, transfusion requirements, the length of the ICU stay and survival (discharge from the hospital) were recorded.
Statistical analysis was carried out using IBM SPSS Statistics $^{\circledR}$ software (SPSS, version 23, SPSS Inc, Chicago, IL). Data was tested for normal distribution using the Kolmogorov-Smirnov test. Normally distributed data is presented as mean \pm standard. Was the data nonnormally distributed, it is reported as median and range. To evaluate the relationship between the individual clinical parameters and ROTEM parameters (ExTEM-CT, -CFT, -MCF, -ML and FibTEM-CT and -MCF), multiple linear regression analysis was performed. Results of the multiple linear regression analysis, in combination with parameters that were significantly different from RI's, were then used to find any independent associations of clinical/biochemical parameters with the above ROTEM parameters. For those parameters that interfere with each other (HR, SAP, SI and lactate, $\mathrm{pH}$, base excess) the parameter showing the strongest power in the linear regression analysis was chosen. Parameters included in the multiple linear regression model consisted of sex, age, cause of the haemoperitoneum, heart rate, temperature, glucose, venous PCV, iCa, base excess and the amount of crystalloid fluids administered prior to ROTEM analysis. A P-value $<0.05$ was considered significant for all statistical analysis.

\section{Results}

A total of 40 dogs were identified and included for analysis. Breeds included mixed breed dogs $(n=6)$, Labrador Retriever ( $n=3)$, Bernese Mountain Dog $(n=3)$, Boxer $(n=3)$, Airedale Terrier $(n=2)$, Cocker Spaniel $(n=2)$ and Giant Schnauzer $(n=2)$. The remaining dogs belonged to various other breeds with on individuum per breed. Mean age of the dogs was $8.4 \pm 3$ years (range: $1.2-13.4$ years) and mean weight $29.7 \pm 13.5 \mathrm{~kg}$ (range: $6.5-69 \mathrm{~kg})$. Twelve of 40 dogs $(30 \%)$ were male intact, $10 / 40(25 \%)$ female, $13 / 40(32.5 \%)$ male neutered and $5 / 40(12.5 \%)$ female neutered.

The main cause of haemoperitoneum was spontaneous bleeding $(31 / 40,77.5 \%)$ due to a splenic $(18 / 31)$ or hepatic mass (4/31) or other bleeding processes (9/31) such as pathological changes in the adrenal glands $(3 / 9)$ or ovaries (2/9) and unknown causes of bleeding(4/9). Nine of $40(22.5 \%)$ dogs were identified with traumatic haemoperitoneum. Sixteen of the $40(40 \%)$ dogs received crystalloid fluids (mean: $9 \mathrm{ml} / \mathrm{kg}$, range: $0-58 \mathrm{ml} / \mathrm{kg}$ ) prior to ROTEM analysis.

Clinical and laboratory parameters at the time of admission are summarized in Table 1. ROTEM results are summarized in Table 2. Mean ExTEM-CT and -CFT and FibTEM-CT were longer than the RI. For all other analysed ROTEM parameters the mean/median was within institutional reference intervals (Table. 2). The
Rotational thromboelastometry (ROTEM) parameters in dogs with haemoperitoneum and their associations with clinical and laboratory signs

A. Martin, A.P. N. Kutter, N.E. Sigrist 
Table 1: Clinical and laboratory parameters at presentation of 40 dogs with haemoperitoneum.

\begin{tabular}{|c|c|c|c|c|c|c|}
\hline Parameter & $\mathrm{N}$ & $\begin{array}{l}\text { Abnormal dogs } \\
n(\%)\end{array}$ & $\begin{array}{l}\text { Mean } \pm \text { SD } \\
\text { Median }\end{array}$ & Minimum & Maximum & $\begin{array}{l}\text { Reference Interval } \\
\mathrm{R}^{2}, 14\end{array}$ \\
\hline Heart Rate (beats per minute) & 39 & $\uparrow 27(69.2 \%)$ & 139 & 68 & 200 & $60-120$ \\
\hline Systolic arterial pressure $(\mathrm{mmHg})$ & 33 & $\begin{array}{l}\uparrow 8(24.2 \%) \\
\downarrow 10(30.3 \%)\end{array}$ & 108 & 60 & 150 & $100-150$ \\
\hline Mean arterial pressure $(\mathrm{mmHg})$ & 35 & $\downarrow 8(22.9 \%)$ & 68 & 40 & 118 & $60-120$ \\
\hline Shock Index & 33 & 个 $29(87.8 \%)$ & $1.23 \pm 2.55$ & 0.53 & 3.08 & $<1.0$ \\
\hline Temperature $\left({ }^{\circ} \mathrm{C}\right)$ & 38 & $\begin{array}{l}\uparrow 4(10.5 \%) \\
\downarrow 13(34.2 \%)\end{array}$ & $37.7 \pm 0.9$ & 35.8 & 39.6 & $37.5-39.0$ \\
\hline Lactate (mmol/L) & 34 & $\begin{array}{l}\uparrow 20(58.8 \%) \\
\downarrow 1(2.9 \%)\end{array}$ & 2.87 & 0.36 & 16.80 & $0.42-2.13$ \\
\hline $\mathrm{pH}$ & 33 & $\downarrow 19(57.6 \%)$ & $7.304 \pm 0.116$ & 6.900 & 7.440 & $7.35-7.45$ \\
\hline Base excess (mmol/L) & 33 & $\downarrow 18(54.5 \%)$ & $-6.30 \pm 4.75$ & -17.6 & 0.3 & $-5-2$ \\
\hline PCV peripheral (\%) & 39 & $\downarrow 36(92.3 \%)$ & $29 \pm 8$ & 16 & 57 & $37-61$ \\
\hline PCV abdominal (\%) & 29 & - & $33 \pm 10$ & 12 & 60 & - \\
\hline Thrombocyte count $(103 / \mu l)$ & 24 & $\downarrow 15(62.5 \%)$ & $131 \pm 95$ & 26 & 411 & $>130$ \\
\hline Glucose (mmol/L) & 37 & $\begin{array}{l}\uparrow 18(48.6 \%) \\
\downarrow 1(2.5 \%)\end{array}$ & $7.57 \pm 2.95$ & 3.2 & 17.2 & $3.9-6.6$ \\
\hline iCa (mmol/L) & 33 & $\downarrow 10(25.6 \%)$ & $1.21 \pm 0.07$ & 1.0 & 1.35 & $1.21-1.41$ \\
\hline
\end{tabular}

iCa, ionized calcium; PCV, packed cell volume; SD, standard deviation; $\uparrow$, number of dogs above the Rl; $\downarrow$, number of dogs below the RI results that deviate from the reference interval are marked in bold

multiple linear regression model showed that a more negative base excess was associated with a prolonged ExTEM-CT $(\mathrm{t}=-2.19, \mathrm{p}=0.04, \beta=-0.5)$ and CFT $(\mathrm{t}=-2.48, \mathrm{p}=0.02, \beta=-0.5)$ and FibTEM-CT $(\mathrm{t}=-2.42$, $p=0.03, \beta=-0.6)$ (Table 3 ). The presence of a trauma was significantly associated with a prolonged $\mathrm{Ex}$ TEM-CFT $(\mathrm{t}=2.25, \mathrm{p}=0.04, \beta=0.40$. All 8 dogs that showed a reduced ExTEM-MCF were thrombocytopenic and had a reduced FibTEM-MCF. Additionally, elevated blood glucose level were associated with a shortened ExTEM-CT $(t=-2.83, p=0.01, \beta=-0.63)$ and FibTEM-CT $(\mathrm{t}=-3.07, \mathrm{p}=0.01, \beta=-0.73)$ and elevated age was associated with increased FibTEM-MCF $(t=2.18, p=0.04, \beta=0.60)$.

Surgery was performed in $29 / 40(72.5 \%)$ cases while the remaining $11 / 40(27.5 \%)$ were treated medically. Seven- teen dogs $(42.5 \%)$ received a blood transfusion, including 10/40 (25\%) dogs receiving erythrocyte concentrate, $2 / 40(5 \%)$ an autotransfusion of abdominal whole blood, $3 / 40(7.5 \%)$ fresh whole blood and 12/40 (30\%) receiving fresh frozen plasma. Mean intensive care unit stay was $54.7 \pm 47$ hours. Thirty of 40 dogs $(75 \%)$ could be discharged from the hospital, while 3 surgically and 7 medically treated dogs (25\%) were euthanized.

\section{Discussion}

The present study describing ROTEM parameters in dogs presenting with haemoperitoneum identified a prolongation of ExTEM- and FibTEM-CT and prolonged ExTEM-CFT. Decreased base excess and trauma were associated with ROTEM signs for hypocoagulabil-

Table 2: ROTEM parameters of 40 dogs presenting with haemoperitoneum

\begin{tabular}{|c|c|c|c|c|c|c|c|}
\hline \multicolumn{2}{|c|}{ Coagulation parameter } & \multirow{2}{*}{$\begin{array}{l}N \\
40\end{array}$} & \multirow{2}{*}{$\begin{array}{l}\text { Abnormal dogs } n(\%) \\
\uparrow 14(35 \%)\end{array}$} & \multirow{2}{*}{$\begin{array}{l}\text { Mean } \pm \text { SD Median } \\
93^{*} \pm 48\end{array}$} & \multirow{2}{*}{$\begin{array}{l}\text { Minimum } \\
23\end{array}$} & \multirow{2}{*}{$\begin{array}{l}\text { Maximum } \\
\mathbf{1 7 4}\end{array}$} & \multirow{2}{*}{$\begin{array}{l}\text { RI } \\
23-87\end{array}$} \\
\hline EXTEM & $\mathrm{CT}$ (sec) & & & & & & \\
\hline & CFT (sec) & 40 & $\begin{array}{l}\uparrow 14(35 \%) \\
\downarrow 1(2.5 \%)\end{array}$ & $382^{*} \pm 367$ & 18 & 2024 & $85-357$ \\
\hline & $\mathrm{MCF}(\mathrm{mm})$ & 40 & $\begin{array}{l}\uparrow 2(5 \%) \\
\downarrow 8(20 \%)\end{array}$ & 42 & 20 & 80 & $32-65$ \\
\hline & ML (\%) & 40 & & $4 \pm 4$ & 0 & 11 & $0-12$ \\
\hline \multirow[t]{2}{*}{ FibTEM } & $\mathrm{CT}$ (sec) & 38 & 个 $15(39.5 \%)$ & $941^{*} \pm 1330$ & 21 & 3600 & $21-112$ \\
\hline & $\operatorname{MCF}(\mathrm{mm})$ & 38 & $\begin{array}{l}\uparrow 4(10.5 \%) \\
\downarrow 4(10.5 \%)\end{array}$ & $5 \pm 8$ & 0 & 45 & $2-9$ \\
\hline
\end{tabular}

CFT, clot formation time; CT, clotting time; MCF, maximal clot formation; ML, maximal lysis; RI, reference interval; SD, standard deviation; $\uparrow$, number of dogs above the RI; $\downarrow$, number of dogs below the RI

results that deviate from the reference interval are marked in bold 
Table 3: multiple linear regression analysis of clinical and biochemical parameters compared to ROTEM parameters in 40 dogs with haemoperitoneum

\begin{tabular}{|c|c|c|c|c|c|c|c|c|c|c|c|}
\hline \multicolumn{2}{|c|}{ ROTEM parameter } & \multirow{2}{*}{$\begin{array}{l}\text { Sex } \\
t=0.28 \\
p=0.78\end{array}$} & \multirow{2}{*}{$\begin{array}{l}\text { Age } \\
\begin{array}{l}\mathrm{t}=0.94 \\
\mathrm{p}=0.36\end{array}\end{array}$} & \multirow{2}{*}{$\begin{array}{l}\text { Cause } \\
\begin{array}{l}\mathrm{t}=0.5 \\
\mathrm{p}=0.62\end{array}\end{array}$} & \multirow{2}{*}{$\begin{array}{l}\text { Heart } \\
\text { rate }\end{array}$} & \multirow{2}{*}{$\begin{array}{l}\text { Temper- } \\
\text { ature } \\
t=0.17 \\
p=0.87\end{array}$} & \multirow{2}{*}{$\begin{array}{l}\text { Glucose } \\
\begin{array}{l}\mathbf{t}=\mathbf{- 2 . 8 3} \\
\mathbf{p}=\mathbf{0 . 0 1} \\
\beta=-0.63\end{array}\end{array}$} & \multirow{2}{*}{$\begin{array}{l}\mathrm{PCV} \text { pe- } \\
\text { ripheral } \\
\mathrm{t}=0.38 \\
\mathrm{p}=0.71\end{array}$} & \multirow{2}{*}{$\begin{array}{l}\text { iCa } \\
\qquad \begin{array}{l}t=-0.32 \\
p=0.75\end{array}\end{array}$} & \multirow{2}{*}{$\begin{array}{l}B E \\
\mathbf{t}=\mathbf{- 2 . 1 9} \\
\mathbf{p}=\mathbf{0 . 0 4} \\
\beta=-\mathbf{0 . 5 0}\end{array}$} & \multirow{2}{*}{$\begin{array}{l}\text { Crys- } \\
\text { talloid } \\
\text { fluids } \\
t=-0.96 \\
p=0.35\end{array}$} \\
\hline EXTEM & $\begin{array}{l}C T \\
R^{2}=0.265\end{array}$ & & & & & & & & & & \\
\hline & $\begin{array}{l}\text { CFT } \\
R^{2}=0.394\end{array}$ & $\begin{array}{l}t=0.29 \\
p=0.77\end{array}$ & $\begin{array}{l}t=0.43 \\
p=0.67\end{array}$ & $\begin{array}{l}t=2.25 \\
p=0.04 \\
\beta=0.40\end{array}$ & $\begin{array}{l}t=1.33 \\
p=0.2\end{array}$ & $\begin{array}{l}t=1.84 \\
p=0.08\end{array}$ & $\begin{array}{l}t=-1.76 \\
p=0.09\end{array}$ & $\begin{array}{l}t=1.04 \\
p=0.31\end{array}$ & $\begin{array}{l}t=-0.35 \\
p=0.73\end{array}$ & $\begin{array}{l}t=-2.48 \\
p=0.02 \\
\beta=-0.50\end{array}$ & $\begin{array}{l}t=-1.42 \\
p=0.17\end{array}$ \\
\hline & $\begin{array}{l}\mathrm{MCF} \\
\mathrm{R}^{2}=0.287\end{array}$ & $\begin{array}{l}t=-0.1 \\
p=0.92\end{array}$ & $\begin{array}{l}t=0.25 \\
p=0.81\end{array}$ & $\begin{array}{l}t=-1.11 \\
p=0.28\end{array}$ & $\begin{array}{l}t=-0.86 \\
p=0.4\end{array}$ & $\begin{array}{l}t=-0.86 \\
p=0.56\end{array}$ & $\begin{array}{l}t=0.6 \\
p=0.56\end{array}$ & $\begin{array}{l}t=0.04 \\
p=0.97\end{array}$ & $\begin{array}{l}t=1.21 \\
p=0.24\end{array}$ & $\begin{array}{l}t=0.61 \\
p=0.55\end{array}$ & $\begin{array}{l}t=0.94 \\
p=0.36\end{array}$ \\
\hline & $\begin{array}{l}\mathrm{ML} \\
\mathrm{R}^{2}=0.269\end{array}$ & $\begin{array}{l}t=-1.44 \\
p=0.16\end{array}$ & $\begin{array}{l}t=2.00 \\
p=0.06\end{array}$ & $\begin{array}{l}t=2.00 \\
p=0.23\end{array}$ & $\begin{array}{l}t=-2.07 \\
p=0.05\end{array}$ & $\begin{array}{l}t=-1.12 \\
p=0.56\end{array}$ & $\begin{array}{l}t=0.04 \\
p=0.97\end{array}$ & $\begin{array}{l}t=0.34 \\
p=0.74\end{array}$ & $\begin{array}{l}t=-1.01 \\
p=0.32\end{array}$ & $\begin{array}{l}t=-1.2 \\
p=0.24\end{array}$ & $\begin{array}{l}t=1.56 \\
p=0.13\end{array}$ \\
\hline \multirow[t]{2}{*}{ FibTEM } & $\begin{array}{l}\text { CT } \\
\mathrm{R}^{2}=0.183\end{array}$ & $\begin{array}{l}t=-0.91 \\
p=0.38\end{array}$ & $\begin{array}{l}t=-0.01 \\
p=0.99\end{array}$ & $\begin{array}{l}t=-0.01 \\
p=0.99\end{array}$ & $\begin{array}{l}t=1.68 \\
p=0.11\end{array}$ & $\begin{array}{l}t=-1.7 \\
p=0.11\end{array}$ & $\begin{array}{l}t=-3.07 \\
p=0.01 \\
\beta=-0.73\end{array}$ & $\begin{array}{l}t=-1.37 \\
p=0.19\end{array}$ & $\begin{array}{l}t=0.84 \\
p=0.41\end{array}$ & $\begin{array}{l}t=-2.42 \\
p=0.03 \\
\beta=-0.60\end{array}$ & $\begin{array}{l}t=-0.4 \\
p=0.69\end{array}$ \\
\hline & $\begin{array}{l}\mathrm{MCF} \\
\mathrm{R}^{22}=0.278\end{array}$ & $\begin{array}{l}t=0.77 \\
p=0.45\end{array}$ & $\begin{array}{l}t=2.18 \\
p=0.04 \\
\beta=0.60\end{array}$ & $\begin{array}{l}t=-0.71 \\
p=0.49\end{array}$ & $\begin{array}{l}t=-0.66 \\
p=0.52\end{array}$ & $\begin{array}{l}t=-0.64 \\
p=0.53\end{array}$ & $\begin{array}{l}t=-0.46 \\
p=0.65\end{array}$ & $\begin{array}{l}t=1.5 \\
p=0.15\end{array}$ & $\begin{array}{l}t=0.39 \\
p=0.7\end{array}$ & $\begin{array}{l}t=-0.4 \\
p=0.7\end{array}$ & $\begin{array}{l}t=1.3 \\
p=0.21\end{array}$ \\
\hline
\end{tabular}

iCa, ionized calcium; BE, base excess; CFT, clot formation time; CT, clotting time; MCF, maximal clot formation; ML, maximal lysis; PCV, packed cell volume; $R^{2}=$ adjusted $R$-Square; $t=T$-Test; $\beta$ = standardized beta coefficient;

numbers in bold show statistically significant association

ity and increased blood glucose concentration and older age were associated with signs for hypercoagulability.

The incidence of hypocoagulability in this study population was $50 \%$. A previous study comparing dogs with spontaneous haemoperitoneum to a matched control group concluded that dogs with spontaneous haemoperitoneum were hypocoaguable based on thrombocytopenia, prolonged prothrombin time (PT) and activated partial thromboplastin time (aPTT) and a low maximal amplitude in tissue factor activated TEG. ${ }^{17}$ The prolonged plasmatic coagulation times identified by Fletcher et al..$^{17}$ are supported by our study that identified one third of the dogs with prolonged ROTEM clotting times and mean ExTEM-CT and FibTEM-CT above the RI, as ExTEM-CT correlates to PT. 12 The clotting time (CT) describes the time from activation of the coagulation cascade until the amplitude of the clot reaches $2 \mathrm{~mm}$ and represents the time until fibrin polymerisation starts. ${ }^{41}$ ExTEM- and FibTEM-CT both rely on the same coagulation factors and both tests are similarly activated. The CT depends on the strength of the activating trigger and the concentration of coagulation factors. ${ }^{42}$ Thus, ExTEM- and FibTEM-CT prolongation identified in our study is thought to be a sign of decreased concentrations of coagulation factors.

Furthermore, our study identified one third of dogs with a prolonged CFT (with mean ExTEM-CFT above the RI) and a low FibTEM-MCF. The maximum clot formation in the FibTEM represents the fibrin clot and correlates with fibrinogen concentration. ${ }^{12}$ Clot formation time describes the initial rate of fibrin polymerization and depends on thrombocyte concentration, plas- ma fibrinogen levels and the amount of coagulation factors. ${ }^{45}$ While median thrombocyte concentration was in the RI, thrombocyte concentration was decreased in two thirds of our dogs and may be causing the CFT prolongation. In addition to the prolonged clotting times, prolonged CFT, thrombocytopenia and decreased FibTEM-MCF (seen in 14/38 dogs), which is suggestive of hypofibrinogenemia, support the pathomechanism of consumption. $5,20,21,24,37$ In contrast to the previous study that identified decreased clot amplitude in dogs with haemoperitoneum compared to control dogs ${ }^{17}$, in the present study only 8 of 40 dogs showed decreased ExTEM-MCF and the reduced MCF was attributed to thrombocytopenia and hypofibrinogenemia.

Dilution coagulopathy, caused by extensive fluid therapy, can present similarly. ${ }^{32,36}$ Dilutional coagulopathy may have influenced our results, however, our analysis showed no statistically significant association between the amount of fluid therapy prior to ROTEM analysis and the ROTEM parameters and we conclude that dogs with haemoperitoneum show signs of consumption coagulopathy.

Base excess, an indicator for systemic hypoperfusion? was significantly associated with prolongations of ExTEM-CT, -CFT and FibTEM-CT. This indicates that hypoperfusion in patients with haemoperitoneum may be one of the causes of CT and CFT prolongation. The endothelium is very sensitive to ischemia ${ }^{4}$ and reacts to it by upregulating thrombomodulin expression and increasing thrombin generation. ${ }^{13}$ Thus, hypoperfusion is believed to start a cascade of events leading to various changes in haemostasis. Those changes include throm- 
Rotational thromboelastometry (ROTEM) parameters in dogs with haemoperitoneum and their associations with clinical and laboratory signs

A. Martin, A.P. N. Kutter, N.E. Sigrist bin formation followed by consumption coagulopathy as well as activation of protein $C$ leading to hyperfibrinolysis; these mechanisms are associated with acute traumatic coagulopathy. ${ }^{21,48} \mathrm{~A}$ relation between hypoperfusion and hyperfibrinolysis has been identified in a previous study. ${ }^{17}$ In contrast to that study, which used an in vitro tissue plasminogen activator activated TEG test for detection of hyperfibrinolysis ${ }^{17}$ and previous studies describing hyperfibrinolysis in dogs with haemoperitoneum. ${ }^{17,40,49}$, none of the dogs in our study showed hyperfibrinolysis. ROTEM is considered the gold standard for the identification of hyperfibrinolysis in people $25,38,43$ and ROTEM was able to identify hyperfibrinolysis in dogs with other disease processes. $29,39,40$ In the present study, the incidence either seems to be low or hyperfibrinolysis is mild, requiring in vitro activation with tissue plasminogen activator as used by Fletcher et al. ${ }^{17}$

Despite the changes found in ROTEM parameters supporting consumption coagulopathy rather than acute traumatic coagulopathy, we identified an association between trauma as the cause of haemoperitoneum and prolongation of ExTEM-CFT. Trauma leads to increased activation of the thrombomodulin and protein $\mathrm{C}$ pathways, resulting in the suppression of coagulation factors and hyperfibrinolysis. ${ }^{11,21}$ Acute traumatic coagulopathy in people is defined by reductions in clot strength and hyperfibrinolysis with only limited prolongation of clotting times ${ }^{10}$. However, recent studies in dogs and cats have identified prolonged CT or plasmatic coagulation times and CFT early after trauma $22,23,29,30$, underlying our findings of a link between trauma and CFT prolongation. As the number of dogs presenting with traumatic haemoperitoneum was small, further studies are required to investigate the pathomechanism associated with traumatic haemoperitoneum in dogs.

Fletcher et al. ${ }^{17}$ reported both hypo- and hyperfibrinogenemic dogs, which corresponds to our findings. Fibrinogen concentrations correlate with FibTEM-MCF12, which was reduced in one third of our dogs and increased in $10.5 \%$. Older dogs of our study population presented with a higher FibTEM-MCF than younger ones. People and dogs develop alterations in the coagulation system that lead to a hypercoagulable and an antifibrinolytic state with increased age.3,15,26 The development of low-grade inflammation with advancing age leads to an increased plasma fibrinogen, pro-inflammatory cytokines, and globulin levels (Ferrucci et al. 2005) and may have manifested in a higher FibTEM-MCF in our dogs.
Interestingly, we identified a significant association between blood glucose concentration and ExTEM-CT as well as FibTEM-CT shortening. Hyperglycaemia is a known phenomenon in dogs with haemorrhagic shock ${ }^{34}$ and was present in $48.6 \%$ of the dogs in our study. Even though the specific mechanisms aren't fully understood, in people hyperglycaemia may activate coagulation. 33,35,44,47 Despite the significant association, none of the dogs presented with a CT below the RI. If age and hyperglycaemia have a protective effect against hypocoagulopathy in dogs with haemoperitoneum remains to be determined.

There are several limitations to this study: only dogs that had ROTEM analysis performed were included, therefore the study needs to be interpreted with respect to its population. Dogs receiving isotonic crystalloid fluids were not excluded and while multiple linear regression analysis did not identify fluid therapy as a significant factor contributing to the prolonged CT and CFT, a dilutional effect cannot completely be excluded. Additionally, the data was compared to institutional RI derived for the machine and were not compared to a matched control group. Furthermore, being a clinical study, the amount and timeframe of blood loss is not known and as haemostasis is a dynamic process, the results may vary under different conditions. To obtain a more detailed insight into pathomechanisms associated with canine haemoperitoneum, further studies with prospective designs are needed.

In conclusion, the changes in ROTEM parameters in this clinical study of dogs with both spontaneous and traumatic haemoperitoneum are similar to those seen with consumption coagulopathy and include CT and CFT prolongation, thrombocytopenia and low FibTEM-MCF leading to $50 \%$ of the dogs presenting hypocoagulable. Base excess and trauma were associated with hypocoagulability, while increasing age was associated with a stronger fibrinogen clot.

\section{Acknowledgements}

The authors would like to thank the "Heubergstiftung" for generous financial support (doctorand salary) and Sonja Hartnack (Department of Veterinary Epidemiology, University of Zurich) for assistance with statistical analysis. 


\section{Paramètres de thromboélastométrie rotationnelle (ROTEM) chez les chiens atteints d'hémopéritoine et leurs associations avec les signes cliniques et de laboratoire}

La thromboélastométrie rotationnelle (ROTEM) est un test de coagulation viscoélastique qui permet d'évaluer l'hémostase depuis la formation du caillot jusqu'à sa dissolution. Le but de cette étude rétrospective était de décrire les changements de l'hémostase à l'aide des paramètres ROTEM chez des chiens présentant un hémopéritoine spontané ou traumatique et d'évaluer d'éventuelles association entre les paramètres cliniques et de laboratoire lors de la présentation avec le ROTEM. Nous avons émis l'hypothèse que les chiens montreraient des signes d'hypocoagulabilité et d'hyperfibrinolyse et que ces changements seraient en corrélation avec le degré d'hypoperfusion. Les dossiers cliniques ont été recherchés surune période de 5 ans pour les chiens présentant un hémopéritoine et pour lesquels une analyse ROTEM à la présentation avait été effectuée. Quarante chiens ont été identifiés et divers paramètres cliniques et de laboratoire (fréquence cardiaque, tension artérielle, glycémie, lactate, concentration d'albumine sérique, PCV (veineux et abdominal), calcium ionisé, $\mathrm{pH}$ et excès basique) ont été relevés. Les paramètres ROTEM suivants ont été analysés: temps de coagulation extrinsèque (ExTEM CT), temps de formation de caillot (ExTEM CFT), fermeté du caillot (ExTEM MCF) et lyse maximale (ExTEM ML), ainsi que fibrinogène (FibTEM) CT et MCF. Par rapport aux intervalles de référence admis, les chiens avec hémoabdomen ont montré une prolongation d'ExTEM et FibTEM CT, ExTEM CFT, $50 \%$ étaient hypocoagulables et $62 \%$ thrombocytopéniques. Aucune hyperfibrinolyse n'a pu être détectée. Plusieurs modèles de régression linéaire ont montré une association entre une diminution de l'excès basique, des traumatismes et des signes ROTEM d'hypocoagulabilité. De plus, l'âge était associé à un caillot de fibrine plus fort. En conclusion, 50\% des chiens présentaient une hypocoagulabilité et les changements dans les paramètres ROTEM sont similaires à ceux observés lors de coagulopathie de consommation. Un excès basique et un traumatisme étaient associés à une hypocoagulabilité, tandis qu'une augmentation de l'âge était associée à un caillot de fibrine plus fort.

Mots clés: Canine, hémoabdomen, hémostase,

hyperfibrinolyse, hypocoagulabilité

\section{Parametri tromboelastometrici (ROTEM) nei cani con emoperitoneo e le loro associazione con i parametri clinici e di laboratorio.}

Come metodo viscoelastico, la tromboelastometria rotazionale (ROTEM) può registrare l'emostasi dalla formazione del coagulo alla dissoluzione. Lo scopo di questo studio retrospettivo era quello di descrivere le modifiche nell'emostasi nei cani presentati con emoaddome spontaneo o traumatico utilizzando i parametri REDEM. Oltre a ciò è stata analizzata la relazione tra $i$ parametri ROTEM e selezionati parametri clinici e di laboratorio. Abbiamo ipotizzato che i cani mostravano segni di ipocoagulabilità e iperfibrinolisi e che questi cambiamenti erano correlati al grado di ipoperfusione. Quaranta cani con emoaddome sono stati presentati nell'ambito dei 5 anni di studio e alla loro presentazione è stata effettuata un'analisi ROTEM. Per questi cani si sono analizzati i parametri clinici come la frequenza cardiaca, la pressione sanguigna, il glucosio e il lattato, l'albumina sierica, l'ematocrito periferico e addominale, il calcio ionizzato, il pH e la base in eccesso. Sono stati valutati i seguenti parametri ROTEM: tempo di coagulazione estrinseca (ExTEM CT), tempo di formazione del coagulo (ExTEM CFT), forza del coagulo (ExTEM MCF) e lisi massima (ExTEM ML) nonché fibrinogeno (fib-tem) CT e MCF. Rispetto agli intervalli di riferimento, i cani hanno mostrato una TAC ExTEM e FibTEM CT prolungata e una CFT ExTEM anch'essa prolungata, il 50\% era ipocoagulabile e il $62 \%$ trombocitopenica. Non è stato possibile dimostrare l'iperfibrinolisi. I modelli di regressione lineare multipla hanno evidenziato una relazione tra la diminuzione dell'eccesso di base, il trauma e i segni ROTEM di ipocoagulabilità. Inoltre, l'età è stata associata ad un coagulo di fibrina più forte. In sintesi, il $50 \%$ dei cani presentava un'ipocoagulazione e i cambiamenti ROTEM si avvicinavano a una coagulopatia da consumo.

Parole chiave: Cani, emoaddome, emostasi, iperfibrinolisi, ipocoagulabilità
Rotational thromboelastometry (ROTEM) parameters in dogs with haemoperitoneum and their associations with clinical and laboratory signs

A. Martin, A.P. N. Kutter N.E. Sigrist 
Rotational thromboelastometry (ROTEM) parameters in dogs with haemoperitoneum and their associations with clinical and laboratory signs

A. Martin, A.P. N. Kutter, N.E. Sigrist

\section{References}

1 Abuelkasem E, Lu S, Tanaka K, Planinsic R, Sakai T: Comparison between thrombelastography and thromboelastometry in hyperfibrinolysis detection during adult liver transplantation. Br J Anaesth. 2016: 116(4): 507-512.

2 Bachmann K, Kutter A, Jud Schefer RS, Sigrist N: Determination of reference intervals and comparison of venous blood gas parameters using a standard and nonstandard collection method in 51 dogs. Schweiz Arch Tierheilkd. 2018: 160(3): 163-170.

3 Barthelemy A, Rannou B, Forterre M, Verwaerde $\mathrm{P}$, Bonnet-Garin JM, Pouzot-Nevoret C, et al.: Differences between coagulation and cytokine profiles in dogs of different ages. Vet J. 2015: 205(3): 410-412.

${ }^{4}$ Bjerkvig CK, Strandenes G, Eliassen HS, Spinella PC, Fosse TK, Cap AP, et al.: "Blood failure“ time to view blood as an organ: how oxygen debt contributes to blood failure and its implications for remote damage control resuscitation. Transfusion. 2016: 56 Suppl 2: S182-189.

${ }^{5}$ Boral BM, Williams DJ, Boral LI: Disseminated Intravascular Coagulation. Am J Clin Pathol. 2016: 146(6): 670-680.

${ }^{6}$ Brohi K, Singh J, Heron M, Coats T: Acute traumatic coagulopathy. J Trauma. 2003: 54(6): 1127-1130.

7 Caputo ND, Kanter M, Fraser R, Simon R: Comparing biomarkers of traumatic shock: the utility of anion gap, base excess, and serum lactate in the ED. Am J Emerg Med. 2015: 33(9): 1134-1139.

${ }^{8}$ Clarke JR, Trooskin SZ, Doshi PJ, Greenwald L, Mode CJ: Time to laparotomy for intra-abdominal bleeding from trauma does affect survival for delays up to 90 minutes. J Trauma. 2002: 52(3): 420-425.

9 Davenport R, Khan S: Management of major trauma haemorrhage: treatment priorities and controversies. Br J Haematol. 2011: 155(5): 537-548.

10 Davenport RA, Brohi K: Cause of trauma-induced coagulopathy. Curr Opin Anaesthesiol. 2016: 29(2): 212-219.

11 Davenport RA, Guerreiro M, Frith D, Rourke C, Platton S, Cohen M, et al.: Activated Protein C Drives the Hyperfibrinolysis of Acute Traumatic Coagulopathy. Anesthesiology. 2017: 126(1): 115-127.

12 Enk NM, Kutter APN, Kuemmerle-Fraune C, Sigrist NE: Correlation of plasma coagulation tests and fibrinogenClauss with rotational thromboelastometry parameters and prediction of bleeding in dogs. J Vet Intern Med. 2019: 33(1): 132-140.

${ }^{13}$ Esmon CT: The protein C pathway. Chest. 2003: 124(3 Suppl): $26 \mathrm{~s}-32 \mathrm{~s}$.

${ }^{14}$ Ettinger SJ, Feldman EC, Cote E: Textbook of Veterinary Internal Medicine. Elsevier, Oxford, GB. 2017.

15 Ferrucci L, Corsi A, Lauretani F, Bandinelli S, Bartali B, Taub DD, et al.: The origins of age-related proinflammatory state. Blood. 2005: 105(6): 2294-2299.

${ }^{16}$ Flatland B, Koenigshof AM, Rozanski EA, Goggs R, Wiinberg B: Systematic evaluation of evidence on veterinary viscoelastic testing part 2: Sample acquisition and handling. J Vet Emerg Crit Care. 2014: 24(1): 30-36.

17 Fletcher DJ, Rozanski EA, Brainard BM, de Laforcade AM, Brooks MB: Assessment of the relationships among coagulopathy, hyperfibrinolysis, plasma lactate, and protein $C$ in dogs with spontaneous hemoperitoneum. J Vet Emerg Crit Care. 2016: 26(1): 41-51.
18 Gando S, Levi M, Toh CH: Disseminated intravascular coagulation. Nat Rev Dis Primers. 2016: 2: 16037

${ }^{19}$ Gando S, Otomo Y: Local hemostasis, immunothrombosis, and systemic disseminated intravascular coagulation in trauma and traumatic shock. Crit Care. 2015: 19: 72.

20 Gando S, Sawamura A, Hayakawa M: Trauma, shock, and disseminated intravascular coagulation: lessons from the classical literature. Ann Surg. 2011: 254(1): 10-19.

${ }^{21}$ Gando S, Wada H, Thachil J: Differentiating disseminated intravascular coagulation (DIC) with the fibrinolytic phenotype from coagulopathy of trauma and acute coagulopathy of trauma-shock (COT/ACOTS). J Thromb Haemost. 2013: 11(5): 826-835.

22 Gottlieb DL, Prittie J, Buriko Y, Lamb KE: Evaluation of acute traumatic coagulopathy in dogs and cats following blunt force trauma. J Vet Emerg Crit Care. 2017: 27(1): 3543.

${ }^{23}$ Holowaychuk MK, Hanel RM, Darren Wood R, Rogers L, O’Keefe K, Monteith G: Prospective multicenter evaluation of coagulation abnormalities in dogs following severe acute trauma. J Vet Emerg Crit Care. 2014: 24(1): 93-104.

${ }^{24}$ Levi M: Disseminated intravascular coagulation. Critical Care Medicine. 2007: 35(9): 2191-2195.

${ }^{25}$ Levrat A, Gros A, Rugeri L, Inaba K, Floccard B, Negrier C, et al.: Evaluation of rotation thrombelastography for the diagnosis of hyperfibrinolysis in trauma patients. $\mathrm{Br} J$ Anaesth. 2008: 100(6): 792-797.

${ }^{26}$ Mari D, Mannucci PM, Coppola R, Bottasso B, Bauer KA Rosenberg RD: Hypercoagulability in centenarians: the paradox of successful aging. Blood. 1995: 85(11): 31443149.

27 McGowan EE, Marryott K, Drobatz KJ, Reineke EL: Evaluation of the use of shock index in identifying acute blood loss in healthy blood donor dogs. J Vet Emerg Crit Care. 2017: 27(5): 524-531.

${ }^{28}$ Meissner A, Schlenke P: Massive Bleeding and Massive Transfusion. Transfus Med Hemother. 2012: 39(2): 73-84

29 Muri B, Schmierer P, Schwarz A, Sigrist N: Hyperfibrinolysis diagnosed with rotational thromboelastometry and treated with tranexamic acid in a dog with acute traumatic coagulopathy. Schweiz Arch Tierheilkd. 2018: 160(4): 227 233.

${ }^{30}$ Muri BM, Jud Schefer R, Sigrist NE: Serial Evaluation of Haemostasis Following Acute Trauma Using Rotational Thromboelastometry in Cats. Vet Comp Orthop Traumatol. 2019: 32(4): 289-296.

${ }^{31}$ Nelson RW, Couto CG: Disorders of the peritoneum), Small animal internal medicine. 6th ed. Mosby, St. Louis, 2019: 510-517.

32 Nishi K, Takasu A, Shinozaki H, Yamamoto Y, Sakamoto T: Hemodilution as a result of aggressive fluid resuscitation aggravates coagulopathy in a rat model of uncontrolled hemorrhagic shock. J Trauma Acute Care Surg. 2013 74(3): 808-812

${ }^{33}$ Rao AK, Chouhan V, Chen X, Sun L, Boden G: Activation of the tissue factor pathway of blood coagulation during prolonged hyperglycemia in young healthy men. Diabetes. 1999: 48(5): 1156-1161.

34 Russel RC, Pardy BJ, Carruthers ME, Bloom SR: Plasma glucagon levels in haemorrhagic shock. Br J Surg. 1977: 64(4): 285-289. 
35 Sakamoto T, Ogawa H, Kawano H, Hirai N, Miyamoto S, Takazoe K, et al.: Rapid change of platelet aggregability in acute hyperglycemia. Detection by a novel laser-light scattering method. Thromb Haemost. 2000: 83(3): 475479.

${ }^{36}$ Schafer N, Driessen A, Bauerfeind U, Frohlich M, Ofir J, Sturmer EK, et al.: In vitro effects of different sources of fibrinogen supplementation on clot initiation and stability in a model of dilutional coagulopathy. Transfus Med. 2016: $26(5): 373-380$

37 Schmaier AL, Miller JL: Coagulation and fibrosis. In: McPherson RA, Pincus MR (eds.), Henry's Clinical Diagnosis and Management by Laboratory Methods Elsevier Saunders, Philadelphia, PA, 2011: 785-800.

38 Schochl H, Frietsch T, Pavelka M, Jambor C: Hyperfibrinolysis after major trauma: differential diagnosis of lysis patterns and prognostic value of thrombelastometry. J Trauma. 2009: 67(1): 125-131.

39 Sigrist NE, Hofer-Inteeworn N, Jud Schefer R, Kuemmerle-Fraune C, Schnyder M, Kutter APN: Hyperfibrinolysis and Hypofibrinogenemia Diagnosed With Rotational Thromboelastometry in Dogs Naturally Infected With Angiostrongylus vasorum. J Vet Intern Med. 2017: 31(4): 1091-1099.

40 Sigrist NE, Schefer RJJ, Kutter APN: Characteristics of hyperfibrinolysis in dogs and cats demonstrated by rotational thromboelastometry (ROTEM). Vet J. 2018: 242: 6773.

${ }^{41}$ Smith SA, McMichael M, Galligan A, Gilor S, Hoh CM: Clot formation in canine whole blood as measured by rotational thromboelastometry is influenced by sample handling and coagulation activator. Blood Coagul Fibrinolysis. 2010: 21(7): 692-702.

42 Smith SA, McMichael MA, Gilor S, Galligan AJ, Hoh CM: Correlation of hematocrit, platelet concentration, and plasma coagulation factors with results of thromboelastometry in canine whole blood samples. Am J Vet Res. 2012: 73(6): 789-798.

${ }^{43}$ Spiel AO, Mayr FB, Firbas C, Quehenberger P, Jilma B: Validation of rotation thrombelastography in a model of systemic activation of fibrinolysis and coagulation in humans. J Thromb Haemost. 2006: 4(2): 411-416.

${ }^{44}$ Stegenga ME, van der Crabben SN, Levi M, de Vos AF, Tanck MW, Sauerwein HP, et al.: Hyperglycemia stimulates coagulation, whereas hyperinsulinemia impairs fibrinolysis in healthy humans. Diabetes. 2006: 55(6): 18071812.

45 Tanaka K, Ogawa S, Bolliger D: A Primer for Clinical Use of Rotational Thromboelastometry. Point of Care. 2012: 11: 77-84.

46 Tieu BH, Holcomb JB, Schreiber MA: Coagulopathy: its pathophysiology and treatment in the injured patient. World J Surg. 2007: 31(5): 1055-1064.

47 Vaidyula VR, Rao AK, Mozzoli M, Homko C, Cheung P, Boden G: Effects of hyperglycemia and hyperinsulinemia on circulating tissue factor procoagulant activity and platelet CD40 ligand. Diabetes. 2006: 55(1): 202-208.

${ }^{48}$ Ward KR: The microcirculation: linking trauma and coagulopathy. Transfusion. 2013: 53 Suppl 1: 38s-47s.

49 Zoia A, Drigo M, Simioni P, Caldin M, Piek CJ: Association between ascites and primary hyperfibrinolysis: A cohort study in 210 dogs. Vet J. 2017: 223: 12-20.

\section{Corresponding author}

Dr. med. vet. Nadja Sigrist

Winterthurerst. 258c

8057 Zürich

+41446358112

E-Mail: nsigrist@vetclinics.uzh.ch
Rotational thromboelastometry (ROTEM) parameters in dogs with haemoperitoneum and their associations with clinical and laboratory signs

A. Martin, A.P. N. Kutter N.E. Sigrist 